BACKGROUND: In inflammatory bowel disease (IBD), cytokine levels (such as interleukin-1 (IL-1)) are elevated. We have shown previously that IL-1 activates phospholipid signaling pathways in intestinal epithelial cells (IEC), leading to increased ceramide levels. Aim: To determine whether ceramide induces apopto$s$ is in IEC.

Methods: Apoptosis was evaluated by an nexin-Vbinding or Hoechst nuclear staining. Levels of bcl-2, bcl-x, bax, p53 and p21 were determined by Western blotting, and cell cycle analysis was determined by flow cytometry.

Results: IL-1 increased ceramide accumulation in a time-dependent and concentration-dependent manner with a peak response at $4 \mathrm{~h}$, with $[\mathrm{IL}-1]=30 \mathrm{ng} / \mathrm{ml}$. Neither IL-1 nor ceramide induced apoptosis in IEC, but they increased bcl-2 levels and decreased bax and p21 levels without affecting bcl-x and p53 levels. They also caused a slight but significant increase in the G2/ M phase. These data suggest a role for ceramide in IBD and suggest a possible mechanism for the enhanced tumorigenic activity in IBD patients.

Key words: Epithelial cells, IL-1, bcl-2, bcl-x, bax, IBD, Inflammation

\section{IL-1 stimulates ceramide accumulation without inducing apoptosis in intestinal epithelial cells}

\author{
Fadia R. Homaidan 1,CA, Marwan E. El-Sabban², \\ Iman Chakroun ${ }^{1}$, Mirvat El-Sibai ${ }^{1}$ and \\ Ghassan S. Dbaibo ${ }^{3}$
}

${ }^{1}$ Department of Physiology, ${ }^{2}$ Department of Human Morphology, and ${ }^{3}$ Department of Pediatrics, Faculty of Medicine, American University of Beirut, Beirut, Lebanon

\author{
${ }^{\mathrm{CA}}$ Corresponding Author \\ Tel: +961 1350000 , ext. 4892 \\ E-mail: fh01@aub.edu.lb
}

\section{Introduction}

Programmed cell death, apoptosis, plays a pivotal role in the development and maintenance of homeostasis within all multicellular organisms. ${ }^{1}$ Apoptosis can be initiated by a variety of stimuli depending on the cell type and on the subcellular component targeted by each type of stimulant.

The sphingomyelin (SM) signal transduction path way has been shown to mediate apoptosis through several cell surface receptors and environmental stresses. $^{2,3}$ The SM pathway is a ubiquitous signaling system in which ceramide plays a central role. Ceramide has been implicated in a variety of cellular processes from cell growth and differentiation and gene transcription to cell death. ${ }^{4,5}$ Many receptors, such as interleukin-1 (IL-1) and tumor necrosis factor$\alpha$ (TNF- $\alpha)$, transduce their signal via the SM pathway. ${ }^{4,6}$ In inflammatory bowel disease (IBD), which includes ulcerative colitis and Crohn's disease, the levels of the cytokine IL-1 levels have been shown to be significantly increased due to the infiltration of inflammatory cells into the intestinal mucosa. We have recently shown that IL-1 causes significant accumulation in ceramide levels in intestinal epithelial cells and that both ceramide and IL- 1 increase prostaglandin $\mathrm{E}_{2}\left(\mathrm{PGE}_{2}\right)$ production through inducing cyclooxygenase-2 (COX-2) synthesis, ${ }^{6,7}$ a major regulator of chloride secretion. This increase in $\mathrm{PGE}_{2}$ levels contributes significantly to the rise in chloride and water secretion observed in IBD patients.

Colorectal cancer represents the major cause for increased morbidity and mortality by malignant disease in inflammatory bowel disease. ${ }^{8}$ Alterations in the level of expression of many proto-oncogenes, such as c-yes, c-fos and c-abl, or expression of aberrant gene productions have been observed in tumors and pre-cancerous conditions. 9 Specifically, however, c-yes-enhanced expression in IBD patients with tumors suggests the importance of this gene in the development of colon cancer in IBD. 9 Increased tumor formation could be attributed to the increased resistance of intestinal cells to apoptosis. Studies in rat intestinal epithelial cells have shown that overexpression of COX-2 leads to phenotypic changes in these cells that would enhance their tumorigenic potential. The cells were resistant to apoptosis and had elevated bcl-2 protein expression, both of which were reversed when the cells were treated with a COX-2 inhibitor. ${ }^{10}$

Although the capacity to carry out apoptosis appears to be inherent to all cells, the susceptibility to apoptosis varies markedly and is influenced by external and cell-autonomous events. The bcl-2 family of proteins constitutes a critical intracellular checkpoint of apoptosis within a distal common cell death pathway. Over-expression of bcl-2 prolonged cell survival of interleukin-3-dependent pro-B-cell lines 
and promyeloid cell lines, and maintained the cells in $\mathrm{G}_{0} \cdot{ }^{11}$ bcl-2 was also capable of protecting $\mathrm{T}$ cells against a variety of apoptotic signals, including glucocorticoids, $\gamma$-irradiation and phorbal esters. ${ }^{12,13}$ Over-expression of bax protein, on the contrary, leads to accelerated apoptotic death in response to a death signal, giving bax its designation as a death agonist. The ratio of bcl-2 to bax is important in determining susceptibility to apoptosis. ${ }^{14}$

In the present study, the effect of elevating ceramide levels, either through IL-1 receptors or by the exogenous addition of membrane-permeable synthetic ceramide, on apoptosis in intestinal epithelial cells was assessed and their effect on the levels on regulators of apoptotic pathway and on cell cycle phases studied. We present evidence that supports the hypothesis that chronic inflammation of the mucosa in the absence of apoptosis may explain the increased propensity of IBD patients to colorectal cancers.

\section{Materials and methods}

\section{Materials}

Human recombinant IL- $1 \alpha$ was a generous gift from Immunex (Seattle, WA, USA). The ECL protein detection kit and PVDF membrane were from Amersham (Amersham, Bucks, UK). Fetal bovine serum (FBS) and bovine serum albumin, penicillin and streptomycin, Dulbecco's Modified Eagle's Medium (DMEM), F-12 medium, pyruvate, non-essential amino acids, goat serum and Earl's balanced salt solution were from Gibco Laboratories (Paisley, UK). Acrylamide, $N^{\prime}, N^{\prime}$-bis-methylene-acrylamide, sodium dodecyl sulfate (SDS), glycine, tris, glycerol, 2 - $\beta$-mercaptoethanol, ammonium persulfate, $N, N, N^{\prime}, N^{\prime}$-tetramethylethylenediamine (TEMED), chloroform, ethylenediamine tetraacetic acid, ethylene glycol-bis $(\beta$ aminoethylether)- $N, N, N^{\prime}, N^{\prime}$-tetraacetic acid (EGTA), methanol, acetic acid, isopropanol, dithiothreitol, imidazole, $\mathrm{LiCl}$, and camptothecine were from Sigma (St Louis, MO, USA). Annexin-V was from Boehringer Mannheim (Mannheim, Germany), and Hoechst nuclear stain was from Molecular Probes (Portland, OR, USA). Mouse antisera to $\mathrm{p} 53$, bcl-2, bcl-x and bax were purchased from Santa Cruz Biotechnology (Santa Cruz, CA, USA). Mouse antiserum to p21 (WAF1) were obtained from Oncogene Research Products (Calbiochem, San Diego, CA, USA), and mouse antibodies to poly(adenosine diphosphateribose) polymerase (PARP) were obtained from Enzyme Systems products (Livermore, CA, USA). Membrane-permeable C2-ceramide was obtained from BioMol (Plymouth Meeting, PA, USA). COX-2 inhibitor L-745,337 (5-methanesulfonamide6-(2,4-difluorothiophenyl)-1-indanone), was a generous gift from the Merck Frosst Center for Therapeutic Research, Quebec, Canada.

\section{Cell culture}

Murine small intestinal epithelial cells (IEC), line Mode-K, ${ }^{15}$ were obtained from Dr P.B. Ernst (University of Texas, Medical Branch, Galveston, TX, USA). Mode-K cells were maintained in DMEM (low glucose) containing $10 \% \mathrm{FBS}, 10 \mathrm{mM}$ sodium pyruvate, and non-essential amino acids. T-84 cells, human colonic cell line, were grown in DMEM/F-12 medium supplemented with $10 \%$ FBS. Cell viability was measured using the trypan blue exclusion assay. An increase in trypan blue positive cells could represent increased cellular necrosis or late changes in cell permeability secondary to apoptosis.

Cells were trypsinized, centrifuged at $200 \times g$, and washed in phosphate-buffered saline (PBS) twice. The cells were then resuspended in PBS : 2x electrophoresis sample buffer, ratio $1: 1$. The sample buffer consisted of $0.25 \mathrm{M}$ Tris- $\mathrm{HCl}$ (pH 6.8), 4\% w/v SDS, $20 \% \mathrm{v} / \mathrm{v}$ glycerol and $0.1 \%$ bromophenol blue. Samples were then boiled for $5 \mathrm{~min}$ and stored at $-80^{\circ} \mathrm{C}$.

\section{Measurement of ceramide levels}

Lipids were extracted from cells according to the method of Bligh and Dyer. ${ }^{16}$ In brief, cell suspensions were washed with PBS and the organic and aqueous phases were separated by chloroform and water. Ceramide levels were measured in the dried samples using a modified diacylglycerol kinase assay. ${ }^{17,18}$ Samples were solubilized in octyl- $\beta$-D-glucoside/dioleoyl phosphatidylglycerol micellar solution $(7.5 \% / 25 \mathrm{mM})$. To the lipid micelles, diglycerol kinase and $\left[\gamma^{32} \mathrm{P}\right]$ adenosine triphosphate were added. Samples were then extracted and lipids were spotted on a silica gel thin-layer chromatography plate. Plates were developed with chloroform/acetone/methanol/acetic acid/water (50:20:15:10:5), air dried and subjected to autoradiography. The radioactive spots corresponding to ceramide phosphate were scraped into scintillation vials and the ${ }^{32} \mathrm{P}$ activity counted in a scintillation counter. Ceramide levels were normalized to lipid phosphate. To measure lipid phosphate, samples were oxidized with $150 \mu 1$ of $70 \%$ perchloric acid at $180^{\circ} \mathrm{C}$ for $1 \mathrm{~h}$. Phosphate levels were measured by the addition of ammonium molybdate and ascorbic acid, and the absorbance read at $820 \mathrm{~nm}$.

\section{Polyacrylamide gel electrophoresis and Western blot analysis}

Approximately $30 \mu \mathrm{g}$ of proteins obtained from cell homogenates from various treatments were loaded onto a 12\% SDS-polyacrylamide gel, subjected to electrophoresis, blotted onto nitrocellulose membrane, and blocked in 5\% non-fat milk containing $0.1 \%$ Tween 20 in Tris-buffered saline for $1.5 \mathrm{~h}$. The blots were incubated with the appropriate antibody at $4^{\circ} \mathrm{C}$ in $1 \%$ tris-buffered saline (TWEEN), washed and reacted with horseradish peroxidase-conjugated 
secondary antibody. The protein bands were detected with chemoluminescence utilizing the ECL detection method and were quantified using ImageQuant software and the Molecular Dynamics Storm 860 System (Molecular Dynamics, Sunnyvale, CA, USA).

\section{Apoptosis studies}

IEC apoptosis was induced with various agents and assessed by annexin-V binding using flow cytometry or by Hoechst nuclear staining using fluorescence microscopy. Apoptosis was induced by either one of the following conditions.

1. Cells were exposed to either ultraviolet (UV) $50-60 \mathrm{~mJ} / \mathrm{cm}^{2}$ using a F5-10 T12 lamp (Westinghouse sunlamp tube (Lighting Supplies, Canton, $\mathrm{OH}, \mathrm{USA}$ ); emission, $313 \mathrm{~nm}$ ) or to $\gamma$-irradiation energy at $527 \mathrm{rad} / \mathrm{min}$ using ${ }^{137} \mathrm{Cs}$ as a source. Both treatments have been shown to cause DNA damage and to mediate radiation-induced cell apoptosis through the p53-dependent pathway. ${ }^{19}$

2. Cells were treated with $1 \mu \mathrm{M}$ camptothecin for $24 \mathrm{~h}$ or with $1 \mathrm{mM} \mathrm{H} \mathrm{H}_{2} \mathrm{O}_{2}$ for $2 \mathrm{~h}$ as positive controls. Camptothecin is an anti-cancer agent, which inhibits DNA topo-isomerase I activity and causes DNA double-strand breaks during DNA replication to induce S-phase-dependent apoptosis, ${ }^{20}$ while $\mathrm{H}_{2} \mathrm{O}_{2}$ induces apoptosis possibly through activation of $\mathrm{p} 53 .{ }^{21}$

The ability of IL-1 or ceramide to induce apoptosis in Mode-K cells was assessed by treating the cells with $30 \mathrm{ng} / \mathrm{ml}$ of IL-1 or with $30 \mu \mathrm{M}$ ceramide, or their combination, for periods ranging from 2 to $24 \mathrm{~h}$.

For annexin $\mathrm{V}$ binding, $10^{6}$ cells were washed in PBS, pelleted at $200 \times g$ for $5 \mathrm{~min}$, and then incubated with FITC-conjugated Annexin- $\mathrm{V}$ in the presence of $1 \mathrm{mM} \mathrm{CaCl}_{2}$. Nuclei of necrotic cells were counter stained with propidium iodide (PI) $(50 \mu \mathrm{g} / \mathrm{ml})$ for $10 \mathrm{~min}$ at room temperature, and cells were screened by flow cytometry using Cell Quest software (approximately 10,000 events). Apoptosis was estimated by the relative amount of FITC-positive/PI-negative cell populations. For Hoechst staining, cells were cultured on coverslips to around $80 \%$ confluent. After the different treatments, cells were washed three times with PBS for $10 \mathrm{~min}$ and then incubated with Hoechst stain $\# 33342(2 \mu \mathrm{g} / \mathrm{ml})$ for $20 \mathrm{~min}$, washed again in PBS three times for $10 \mathrm{~min}$ and fixed in formaldehyde (4\%), and observed under a fluorescence microscope. Apoptotic cells were recognized by the typical appearance of condensed chromatin in the nucleus and apoptotic bodies.

\section{Cell cycle analysis}

Cells were harvested at pre-determined time-points after treatment, washed twice with cold PBS and fixed
Table 1. Effect of interleukin-1 (IL-1) on ceramide production in intestinal epithelial cells (IEC) ${ }^{a}$

\begin{tabular}{lcc}
\hline Time $(\mathrm{h})$ & \multicolumn{2}{c}{ Ceramide levels $(\mathrm{pmol} / \mathrm{nmol})$} \\
\cline { 2 - 3 } & Mode-K cells $(n=6)$ & T-84 cells $(n=3)$ \\
\hline 0 & $2.6 \pm 0.8$ & $3.0 \pm 0.1$ \\
1 & N.D. & $10.4 \pm 0.6^{*}$ \\
2 & $6.7 \pm 1.2^{*}$ & $9.2 \pm 1.0^{*}$ \\
4 & $10.4 \pm 1.3^{*}$ & $7.7 \pm 0.5^{*}$ \\
6 & $6.5 \pm 1.2^{*}$ & $3.2 \pm 0.04$ \\
12 & $6.3 \pm 1.3^{*}$ & $3.0 \pm 0.15$ \\
\hline
\end{tabular}

Data presented as mean \pm standard error.

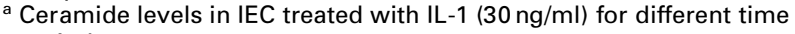
periods.

$* p<0.05, p$ value represents the comparison of the effect of IL-1 $\beta$ on ceramide production as compared with untreated cells.

in methanol $\left(-20^{\circ} \mathrm{C}\right)$. Subsequently, cells were rinsed with PBS, treated with Tris-HCl buffer ( $\mathrm{pH}$ 7.4) containing $1 \%$ RNase and stained with PI (final concentration, $50 \mu \mathrm{g} / \mathrm{ml}$ ). Cells were centrifuged and resuspended in $4 \%$ formaldehyde. The distribution of different DNA contents was determined using a FACScan flow cytometer (Becton Dickinson, San Jose, CA, USA). In each sample, 10,000 ungated events were acquired. Analysis of cell cycle distribution (including apoptosis) was performed (Becton Dickinson).

Statistical analyses were performed with Student's $t$-tests for paired and unpaired data. Unless specified, all results are presented as the mean \pm standard error. IL-1 is used throughout the paper to denote IL- $1 \alpha$.

\section{Results}

\section{IL-1 increases ceramide levels in IEC}

IL-1 has been shown to play a role in stimulating sphingomyelin breakdown. IEC were treated with different concentrations of IL-1 for various time periods and the levels of ceramide measured. Basal ceramide levels in Mode-K and T-84 cells were $2.6 \pm$ 0.8 and $3.0 \pm 0.1 \mathrm{pmol} / \mathrm{nmol}$ of phosphate, respectively. These levels were increased significantly with treatment of the cells with [IL-1] $=30 \mathrm{ng} / \mathrm{ml}$, and peaked in increase at 4 and $1 \mathrm{~h}$ for Mode-K cells and T-84 cells, respectively (Table 1 ). The maximum increase in ceramide accumulation was similar for the two cell lines. However, maximum levels of ceramide were reached at different rates. Ceramide increase was also dependent on the concentration of IL-1 used. The maximum increase in ceramide levels was reached at $[\mathrm{IL}-1]=10-30 \mathrm{ng} / \mathrm{ml}$ for both cell lines.

The effect of ceramide and IL-1 on IEC apoptosis

Ceramide has been directly linked to the induction of cytokine-mediated apoptosis. ${ }^{22}$ To test whether IL-1 


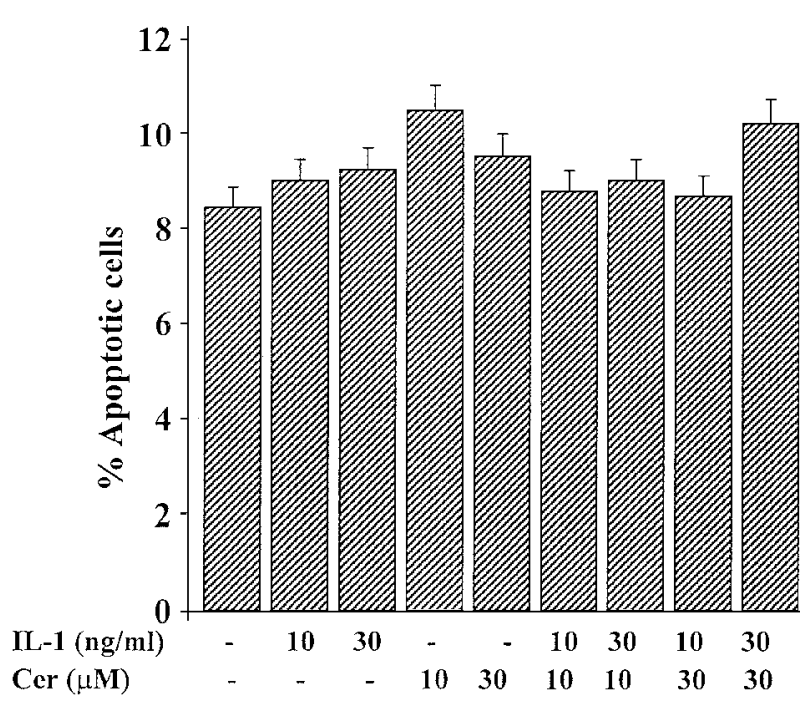

FIG. 1. The effect of ceramide and IL-1, and their combination, on inducing apoptosis in Mode-K cells measured $24 \mathrm{~h}$ after treatment $(n=4)$. Apoptosis was measured using Annexin-V-Flous kit and cells wereanalyzed by flow cytometry. IL-1 and/or ceramide did not increase the apoptotic index in any of the treatments.

causes apoptosis, IEC were treated with IL-1 $(10-30 \mathrm{ng} / \mathrm{ml})$, with ceramide $(10-30 \mu \mathrm{M})$, or with a combination of both ceramide and IL-1 at different concentrations. In Mode-K cells, IL-1 did not increase the number of apoptotic cells measured at $24 \mathrm{~h}$; neither did ceramide or their combination in Mode-K cells (Fig. 1). Similarly, no increase in apoptosis was observed in T-84 cells as assessed by trypan blue exclusion assay (Table 2).

In contrast, apoptosis was induced by treatment of the IEC with hydrogen peroxide, exposure to $\gamma$-irradiation or UV-irradiation (to test whether the p53-dependent apoptotic pathway is functional in these cells), or camptothecin (an example is illustrated in Fig. 2). These treatments resulted in increased apoptosis as measured by annexin FITC fluorescence using flow cytometry or by Hoechst staining using fluorescence microscopy. This indicates that IL-1 and/or ceramide treatment did not induce apoptosis in IEC, although the cells are capable of undergoing apoptosis as observed by other test agents or treatments.

We have reported recently that IL-1 induces the expression of COX-2 in IEC $^{6}{ }^{6}$ through ceramide. Increased COX-2 levels have been associated with inhibition of apoptosis through increasing bcl-2 pro-
Table 2. Effect of interleukin-1 treatment on T-84 cells ${ }^{\mathrm{a}}$

Time (h)

$\%$ Dead cells

(mean \pm standard error)

\begin{tabular}{rr}
\hline 0 & $1.04 \pm 0.00$ \\
1 & $0.79 \pm 0.01$ \\
2 & $1.53 \pm 0.01$ \\
4 & $1.65 \pm 0.48$ \\
12 & $1.63 \pm 0.93$ \\
24 & $1.89 \pm 1.08$ \\
\hline
\end{tabular}

${ }^{a}$ T-84 cells were treated with interleukin-1 $(30 \mathrm{ng} / \mathrm{ml})$ for different time periods. Cell viability was measured using the trypan blue exclusion assay.

tein expression. ${ }^{10}$ Pre-treatment of Mode-K cells with the COX-2 inhibitor (500 nM) L-745,337 and then treatment with ceramide resulted in a significant increase in apoptosis as assessed by trypan blue exclusion assay (Table 3), which is in accordance with what has been observed in rat intestinal epithelial cells. ${ }^{10}$

\section{The effect of ceramide and IL-1 on apoptosis regulating proteins}

We examined the level of expression of the major cellular regulators of apoptosis that include bcl-2, bcl$\mathrm{x}$ and bax by Western blot analysis. In control Mode-K cells, there was constitutive expression of all three proteins (Fig. 3). The addition of IL-1 resulted in a sharp decrease in bax expression $2 \mathrm{~h}$ post treatment, was significantly decreased $6 \mathrm{~h}$ after treatment and was completely abolished by $24 \mathrm{~h}$ (Fig. 3A). Ceramide treatment as well as a combination of ceramide and IL1 caused an effect similar to that of IL-1 alone.

In contrast to bax downregulation, bcl-2 expression was significantly increased by treatment of the cells with IL-1 and/or ceramide (Fig. 3), while bcl-x expression was not modified (data not shown). These results suggest that IL-1 exerts its effect through ceramide accumulation to decrease the levels of proapoptotic factors and to increase anti-apoptotic proteins, hence shifting from the apoptotic pathway to increasing the production of eicosanoids as was observed earlier. ${ }^{7}$ Further evidence that IL-1 or ceramide treatment did not induce apoptosis in Mode$\mathrm{K}$ cells is that neither the level or the integrity of PARP enzyme was changed (data not shown).
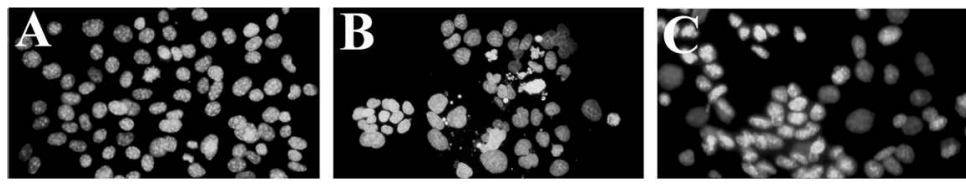

FIG. 2. Ceramide had no effect on apoptosis in Mode-K cells (C), although cells did undergo apoptosis when exposed to ultraviolet rays (B) as compared with a time control (A). 
Table 3. Percentage of apoptosis in Mode-K cells

Treatment

$\%$ Dead cells

$(\text { mean } \pm \text { standard error })^{a}$

Control untreated cells

L-745,337 $(500 \mathrm{nM}), 24 \mathrm{~h}$ treatment

Ceramide $(30 \mu \mathrm{M}), 24 \mathrm{~h}$ treatment

$\mathrm{L}-745,337^{\mathrm{C}}(500 \mathrm{nM})$, pre-treatment for $1 \mathrm{~h}+$ ceramide $(30 \mu \mathrm{M}), 24 \mathrm{~h}$ treatment

$4.6 \pm 0.1$
$4.3 \pm 0.1$

$4.3 \pm 0.5$

$\mathrm{H}_{2} \mathrm{O}_{2}(1 \mathrm{mM}), 2 \mathrm{~h}$ treatment

$11.6 \pm 1.4$

$41.0 \pm 10.0$

${ }^{a}$ Mode-K cell viability was measured using the trypan blue exclusion assay.

b Number of experiments.

${ }^{c}$ COX-2 inhibitor used, L-745,337 (5-methanesulfonamide-6-(2,4-difluorothiophenyl)-1-indanone) .

The effect of ceramide and IL-1 on p53 and p21 protein levels

The levels of p53 and p21 were examined in cells treated with IL-1 or ceramide at different concentrations and different time periods. None of the treatments had any effect on p53 levels, as assessed by Western blotting assays (Fig. 4). However, p21 levels were decreased significantly within $1 \mathrm{~h}$ after treatment with either IL-1 or ceramide and peaked at $4 \mathrm{~h}$, then returned to basal levels after $24 \mathrm{~h}$.

\section{The effect of ceramide and IL-1 on cell cycle}

To investigate whether ceramide and/or IL-1 affect cell proliferation, cell cycle analysis was performed by measuring DNA content as described in 'Materials and methods'. No major modification of the distribution of the different cell cycle phases (pre- $G_{0}, G_{0} / G_{1}, S$ and $G_{2} / M$ phases) was observed except for a moderate increase in the percentage of cells in the $G_{2} / M$ phase in IL-1 and/or ceramide-treated cells, resulting in a decrease in the percentage of cells in the $G_{0} / G_{1}$ phases (Fig. 5).

Cell cycle analysis was also employed for the evaluation of apoptosis. The percentages of cells in the pre- $G_{0} / G_{1}$ phase (representing, at least in part, apoptotic cells) in control as well as in treated cells were not different $(3.25 \pm 0.2 \%$ in control untreated

\section{A}

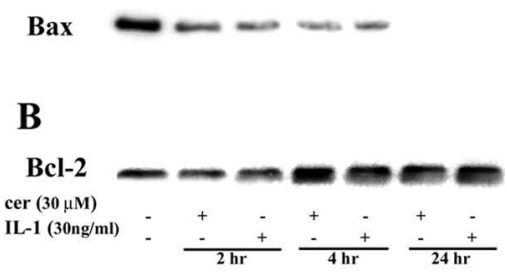

FIG. 3. A representative Western blot $(n=5)$ showing the effect of IL-1 $(30 \mathrm{ng} / \mathrm{ml})$ and ceramide $(30 \mu \mathrm{M})$ on the levels of protein regulators of apoptosis. (A) Both IL-1 and ceramide caused a sharp decrease in bax protein levels $1 \mathrm{~h}$ after treatment, and bax was abolished by $24 \mathrm{~h}$. (B) Both IL-1 and ceramide caused an increase in bcl-2 levels $4 \mathrm{~h}$ after treatment. cells versus $4.95 \pm 2.4$ in $30 \mathrm{ng} / \mathrm{ml}$ of IL-1-treated cells; not significant). Thus, the induction of apoptosis by these treatments was ruled out.

\section{Discussion}

IL-1, a pro-inflammatory cytokine, is produced and secreted by inflammatory cells and other cell types in response to a variety of stimuli. It is involved in many inflammatory responses and is a potent inducer of arachidonic acid mobilization and its metabolism to prostaglandins and other eicosanoids, a hallmark of inflammatory response. Several second messengers have been shown to mediate the effects of this cytokine. In intestinal epithelial cells, we have shown that IL-1 elicits its effects mainly through activating phospholipid messengers. It increases phospholipase $\mathrm{A}_{2}\left(\mathrm{PLA}_{2}\right)$ activity, ${ }^{23}$ and increases the expression of $\mathrm{PLA}_{2}$-activating protein and the enzyme COX-2.6,7 These effects lead to increased levels of $\mathrm{PGE}_{2}$ and to a subsequent increase in $\mathrm{Cl}^{-}$secretion. ${ }^{24}$ Bioactive lipids, generated in response to activation of various lipases, serve as intracellular and extracellular mediators in cell signaling. They play important roles in a variety of processes involving cell-cell communication, inflammation, host-defense mechanisms, and in ischemia reperfusion. Ceramide, which is generated from SM by the action of the ubiquitous enzyme sphingomyelinase (SMase), serves as an important

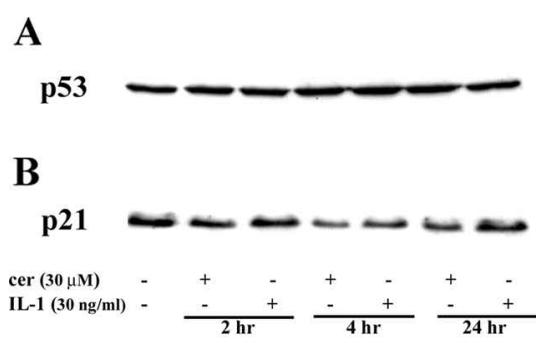

FIG. 4. A representative Western blot $(n=4)$ showing: $(\mathrm{A})$ the lack of effect of IEC treatment by IL-1 $(30 \mathrm{ng} / \mathrm{ml})$ and/or ceramide on p53 levels, and (B) the decrease in p21 levels by IL-1 and/or ceramide. 


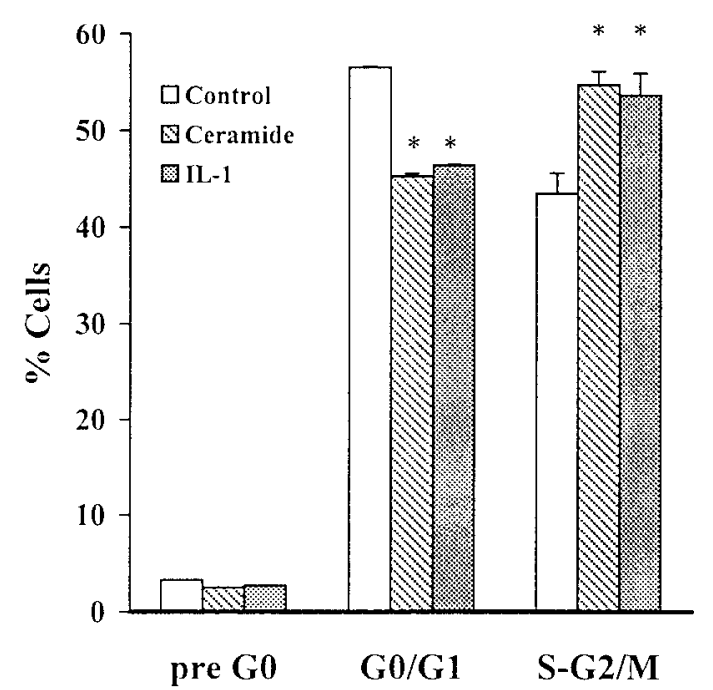

FIG. 5. Effects of IL-1 $(30 \mathrm{ng} / \mathrm{ml})$ and ceramide $(30 \mu \mathrm{M})$ on the cell cycle distribution of IEC after $24 \mathrm{~h}$ of treatment. Histogram-related nuclear DNA contents were measured by flow cytometry as described in 'Materials and methods'. The sum of $G_{0} / G_{1}$ and $S-G_{2} / M$ phases is normalized to $100 \%(n=3)$.

pleiotropic signal transducer in apoptosis as well as in cell proliferation and differentiation. ${ }^{4,5,25}$ All sphingolipids contain ceramide as the basic hydrophylic component that is released by activated SMase. SMase can be activated by a variety of extracellular signals and stimulants including TNF- $\alpha, \gamma$-interferon, IL-1 and ionizing radiation. The nature of ceramide-mediated signaling suggests that the SM pathway may link downstream to a variety of effector systems. Evidence suggest that ceramide play a role in signaling of both the pro-inflammatory and apoptotic effects of TNF$\alpha .{ }^{26}$ Ceramide also stimulates cytokine production in some cell types, suggesting a role in extracellular signaling via the cytokine network. ${ }^{27}$ A connection between cytokine signaling, inflammation and the SM pathway have also been suggested ${ }^{4}$ by virtue of the effects of ceramide on the induction of $\mathrm{PGE}_{2}$ production. Ceramide has also been implicated in increasing $\mathrm{PLA}_{2}$ activity and stimulating the transcription of cyclooxygenase in inflammation, leading to increased production of $\mathrm{PGE}_{2} \cdot{ }^{4,28}$ However, we have shown recently that ceramide increased the production of $\mathrm{PGE}_{2}$ in intestinal epithelial cells through inducing COX-2 synthesis without any effect on PLA ${ }_{2}$ activity. ${ }^{6}$ The generation of eicosanoids such as $\mathrm{PGE}_{2}$ represents an important signaling system utilized by many cytokine/growth factor receptors. Hence, it appears that there is a cross-talk between receptor signaling through activation of the SM pathway and eicosanoid production.

Ceramide has also been implicated in cytokinemediated apoptosis. ${ }^{22,29}$ This was supported by the finding that apoptosis was induced by exogenous bacterial SMase, which cleaves SM to result in ceramide. In the present study, we show that neither ceramide nor IL-1 increase IEC apoptosis. These data suggest that ceramide does not activate the apoptotic pathway, but rather feeds into the eicosanoid metabolic pathway. Similar findings have been reported recently in human leukemic cells ${ }^{30}$ and in rat alveolar cells. ${ }^{31}$ Exogenous ceramide failed to trigger apoptosis in human myelogenous leukemic cells ${ }^{30}$ although TNF- $\alpha$-induced apoptosis was blocked by a sphingomyelinase inhibitor. This indicates that ceramide was necessary but not sufficient for TNF- $\alpha$-induced apoptosis. Mallampalli et al. also observed that ceramide resulting from TNF- $\alpha$ activation of SM hydrolysis might activate the mitogen-activated protein kinase and nuclear factor (NF)- $\mathrm{B}$ pathways without increasing programmed cell death in alveolar type II epithelial cells. ${ }^{31}$

In addition to the tightly regulated pro-apoptotic mechanisms, mammalian cells also operate antiapoptotic mechanisms to constrain apoptosis. These include the bcl-2 system, ${ }^{32-34}$ loss of $\mathrm{p} 53$ activity, ${ }^{35,36}$ activation of NF- $\mathrm{KB},{ }^{37,38}$ and activation of the 1,2-diacylglycerol-protein kinase $\mathrm{C}$ signaling system. ${ }^{39,40}$ These anti-apoptopic systems and the pro-apoptotic systems are both subject to regulation. While originally bcl-2-related proteins were reported to confer anti-apoptotic protection, it was subsequently shown that some members of this family serve as proapoptotic factors. ${ }^{32,34} \mathrm{bcl}-2$ and bcl-x are the main members of this family that inhibit apoptosis, while bax and bad are the two best known pro-apoptotic factors. Prolonged cell survival with resistance to apoptosis can be a primary oncogenic event. Evidence has emerged that a principal contribution from the loss of $\mathrm{p} 53$ function is the elimination of a death pathway. ${ }^{41,42}$ In select settings, stimuli that induce p53 result in the expression of bax. ${ }^{43}$ In the present study, p53 levels as well as bcl-x were not affected by treatment of the cells by IL-1 and/or ceramide, while bax levels were decreased significantly and bcl-2 levels were increased, further supporting the finding that ceramide does not lead the cells into the apoptotic pathway. Furthermore, the increased proliferation observed in treated intestinal epithelial cells correlated with the decreased protein levels of the cyclin-dependent kinase inhibitor p21 reported in this study.

Recent studies have shown that induction of $\mathrm{PGE}_{2}$ and COX-2 levels inhibit apoptosis in IEC ${ }^{44}$ through inducing bcl-2 expression but with no effect on bax expression. This could explain the lack of apoptosis in Mode- $K$ cells since we have shown that ceramide and IL-1 induce COX-2 and/or PLA 2 , both leading to increased levels of $\mathrm{PGE}_{2}{ }^{6}$

These data suggest that while ceramide might still initiate the upstream apoptotic pathway, it does not commit the cell to the death process. The bcl-2 protein family can still reverse the process at multiple checkpoints along the apoptotic-signaling pathway. 
Apoptosis plays a major role in the pathogenesis of disease and its management. Improved understanding of mechanisms of pro-apoptosis and anti-apoptosis and their coordinated function may yield opportunities for pharmacological interventions in human disease with important potentials for clinical applications. The anti-apoptotic effects caused by IL-1 and ceramide suggest a role for them in IBD and propose a possible mechanism for the enhanced tumorigenic activity of intestinal epithelial cells in IBD patients.

ACKNOWLEDGEMENTS. This project is supported by grants from the American University of Beirut Medical Practice Plan, the Lebanese National Research Council and the Diana Tamari Sabbagh Foundation. I.C. is supported by a grant from the American University of Beirut Medical Practice Plan and University Research Board. The authors thank Dr Ali Bazarbachi (Department of Internal Medicine, American University of Beirut) for his valuable discussion.

\section{References}

1. Raff MC. Social controls on cell survival and death. Nature 1992; 356 : 397-400.

2. Kolesnick R, Golde DW. The sphingomyelin pathway in tumor necrosis factor and interleukin-1 signaling. Cell 1994; 77 : 325-328.

3. Verheij M, Bose R, Lin XH, et al. Requirement for ceramide-initiated SAPK/JNK signaling in stress-induced apoptosis. Nature 1996; 380 : 75-79.

4. Ballou LR, Laulederkind SJF, Rosloniec EF, et al. Ceramide signaling and the immune response. Biochim Biophys Acta 1996; 1301: 273-287.

5. Kolesnick RN, Haimovitz-Friedman A, Fuks Z. The sphingomyelin signal transduction pathway mediates apoptosis for tumor necrosis factor, Fas, and ionizing radiation. Biochem Cell Biol 1994; 72: 471-474.

6. Homaidan FR, Chakroun I, Dbaibo GS, et al. IL-1 activates two phospholipid signaling pathways in intestinal epithelial cells. Inflamm Res 2001; 50: 375-381.

7. Homaidan FR, Zhao LM, Martin C, et al. The mechanism of action of IL-1 on rabbit intestinal epithelial cells. Med Inflamm 1999; 8: 189-197.

8. Pohl C, Hombach A, Kruis W. Chronic inflammatory bowel disease and cancer. Hepatogastroenterology 2000; 47: 57-70.

9. Alexander RJ, Panja A, Kaplan-Liss E, et al. Expression of protooncogeneencoded mRNA by colonic epithelial cells in inflammatory bowel disease. Dig Dis Sci 1996; 41: 660-669.

10. Tsujii M, DuBois RN. Alterations in cellular adhesion and apoptosis in epithelial cells overexpressing prostaglandin endoperoxide synthase 2 . Cell 1995; 83: 493-501.

11. Korsmeyer $\mathrm{SJ}$. Bcl-2 initiates a new category of oncogenes: regulators of cell death. Blood 1992; 80: 879-886.

12. Sentman CL, Shutter JR, Hockenberry D, et al. bcl-2 inhibits multiple forms of apoptosis but not negative selection in thymocytes. Cell 1994; 67: 879-888.

13. Strasser A, Harris AW, Cory S. bcl-2 transgene inhibits T cell death and perturbs thymic self-censorship. Cell 1991; 67: 889-899.

14. Oltvai ZN, Milliman CL, Korsmeyer SJ. Bcl-2 heterodimerizes in vivo with a conserved homolog, Bax, that accelerates programmed cell death. Cell 1993; 74: 609-619.

15. Vidal K, Grosjean I, Revillard JP, et al. Immortalization of mouse intestinal epithelial cells by SV40-large T gene. Phenotypic and immune characterization of the Mode-K cell line. J Immunol Methods 1993; 166: $63-73$.

16. Bligh EG, Dyer WJ. A rapid method of total lipid extraction and purification. Can J Biochem Physiol 1959; 37: 911-917.

17. Okazaki T, Bielawska A, Bell RM, et al. Role of ceramide as a lipid mediator of 1alpha, 2 5-dihydroxy vitamin $\mathrm{D}_{3}$-induced HL-60 cell differentiation. J Biol Chem 1990; 265: 15823-15831.

18. Preiss JE, Loomis CR, Bell RM, et al. Quantitative measurement of sn1,2-diacylglycerols. Methods Enzymol 1987; 141: 294-300.
19. Denmeade SR, Isaacs JT. Programmed cell death (apoptosis) and cancer chemotherapy. Cancer Control 1996; 3: 303-309.

20. Huang TT, Wuerzberger-Davis SM, Seufzer BJ, et al. NF-кB activation by camptothecin. A linkage between nuclear DNA damage and cytoplasmic signaling events. J Biol Chem 2000; 275: 9501-9509.

21. Huang C, Li J, Zheng R, et al. Hydrogen peroxide-induced apoptosis in human hepatoma cells is mediated by CD95(APO-1/Fas) receptor/ligand system and may involve activation of wild-type p53. Mol Biol Rep 2000; 27: 1-11.

22. Hannun YA, Obeid LM. Mechanisms of ceramide-mediated apoptosis. Adv Exp Med Biol 1997; 407: 145-149.

23. Homaidan FR, Zhao LM, Burakoff R. IL-1 induces the synthesis of phospholipase- $\mathrm{A}_{2}$ activating protein in rabbit colonic epithelial cells. $\mathrm{Am}$ J Physiol 1997; 272: G1338-G1346.

24. Homaidan FR, Desai H, Zhao LM, et al. Regulation of electrolyte transport with IL-1 $\beta$ in rabbit colonic epithelial cells. Mediat Inflamm 1995; 4: 61-66.

25. Hannun YA, Bell RM. Functions of sphingolipids and sphingolipid degradation breakdown products in cellular regulation. Science 1989; 243: $500-507$

26. Wiegmann K, Schutze S, Machleidt T, et al. Functional dichotomy of neutral and acidic sphingomyelinases in tumor necrosis factor signaling. Cell 1994; 78 : 1005-1015.

27. Ballou LR. Ceramide and inflammation. In Hannun YA, ed. Sphingolipidmediated signal transduction. Georgetown, TX: R.G. Landes Co., 1997: 35-51.

28. Hayakawa M, Jayadev S, Tsujimoto M, et al. Role of ceramide in stimulation of the transcription of cytosolic phospholipase $A_{2}$ and cyclooxygenase 2. Biochem Biophys Res Commun 1996; 220: 681-686.

29. Gamard CJ, Dbaibo GS, Liu B, et al. Selective involvement of ceramide in cytokine-induced apoptosis. J Biol Chem 1997; 272: 16474-16481.

30. Higuchi M, Singh S, Jaffrezou JP, et al. Acid sphingomyelinase-generated ceramide is needed but not sufficient for TNF-induced apoptosis and nuclear factor-kB activation. J Immunol 1996; 156: 297-304.

31. Mallampalli RK, Peterson EJ, Carter AB, et al. TNF-a increases ceramide without inducing apoptosis in alveolar type II epithelial cells. Am J Physiol 1999; 276: L481-L490.

32. Korsmeyer SJ, Yin XM, Oltvai ZN, et al. Reactive oxygen species and the regulation of cell death by the Bcl-2 gene family. Biochim Biophys Acta 1995; $1271: 63-66$.

33. Kajewski TF, Thompson CB. Apoptosis meets signal transduction: elimination of BAD influence. Cell 1996; 7: 589-592.

34. Yang E, Korsmeyer SJ. Molecular thanatopsis: a discourse on the BCL2 family and cell death. Blood 1996; 88: 386-401.

35. Santana P, Pena LA, Haimovitz-Friedman A, et al. Acid sphingomyelinase deficient human lymphoblasts and mice are effective in radiationinduced apoptosis. Cell 1996; 86: 189-199.

36. Chen M, Quintans J, Fuks Z, et al. Suppression of Bcl-2 messenger RNA production may mediate apoptosis after ionizing radiation, tumor necrosis factor alpha, and ceramide. Cancer Res 1995; 55: 991-994.

37. Lazebnik YA, Kaufmann SH, Desnoyeres S, et al. Cleavage of poly(ADPribose) polymerase by a proteinase with properties like ICE. Nature 1994; 371:346-347.

38. Beg AA, Baltimore D. An essential role for NF-KappaB in preventing TNFalpha-induced cell death. Science 1996; 274 : 782-784.

39. Haimovitz-Friedman A, Kan CC, Ehleiter D, et al. Ionizing radiation acts on cellular membranes to generate ceramide and induce apoptosis. $J \operatorname{Exp}$ Med 1994; $180: 525-535$

40. Jarvis WD, Fornari Jr FA, Browning JL, et al. Attenuation of ceramideinduced apoptosis by diglyceride in human myeloid leukemia cells. $J$ Biol Chem 1994; 269: 31685-31692.

41. Lowe SW, Bodis S, McClatchey A, et al. p53 status and the efficacy of cancer therapy in vivo. Science 1994; 266: 807-810.

42. Symonds $\mathrm{H}$, Krall L, Remington L, et al. p53-dependent apoptosis suppresses tumor growth and progression in vivo. Cell 1994; 78 : $703-711$.

43. Miyashita T, Reed JC. Tumor suppressor p53 is a direct transcriptional activator of the human bax gene. Cell 1995; 80: 293-299.

44. Sheng $\mathrm{H}$, Shao J, Morrow JD, et al. Modulation of apoptosis and Bcl-2 expression by prostaglandin $\mathrm{E}_{2}$ in human colon cancer cells. Cancer Res 1998; 58: 362-366.

\section{Received 29 October 2001;} accepted 16 November 2001 


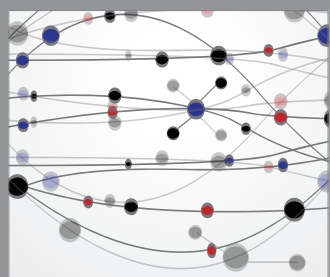

The Scientific World Journal
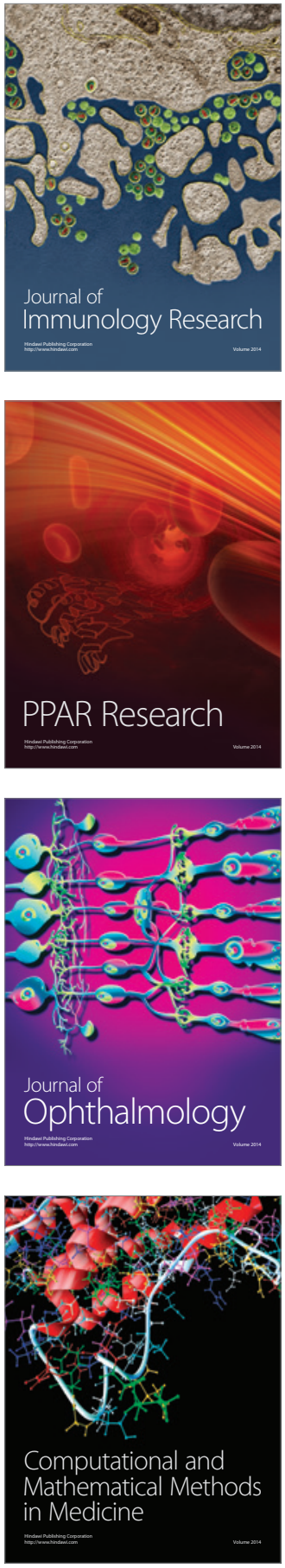

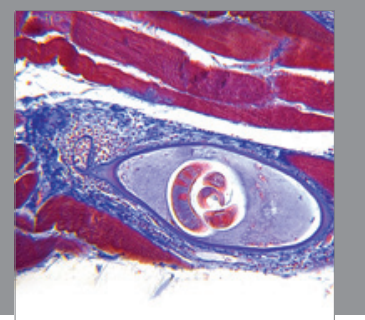

Gastroenterology

Research and Practice
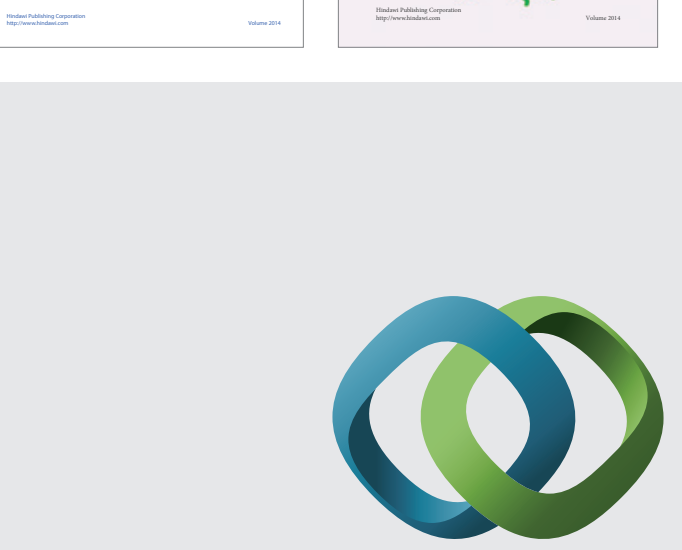

\section{Hindawi}

Submit your manuscripts at

http://www.hindawi.com
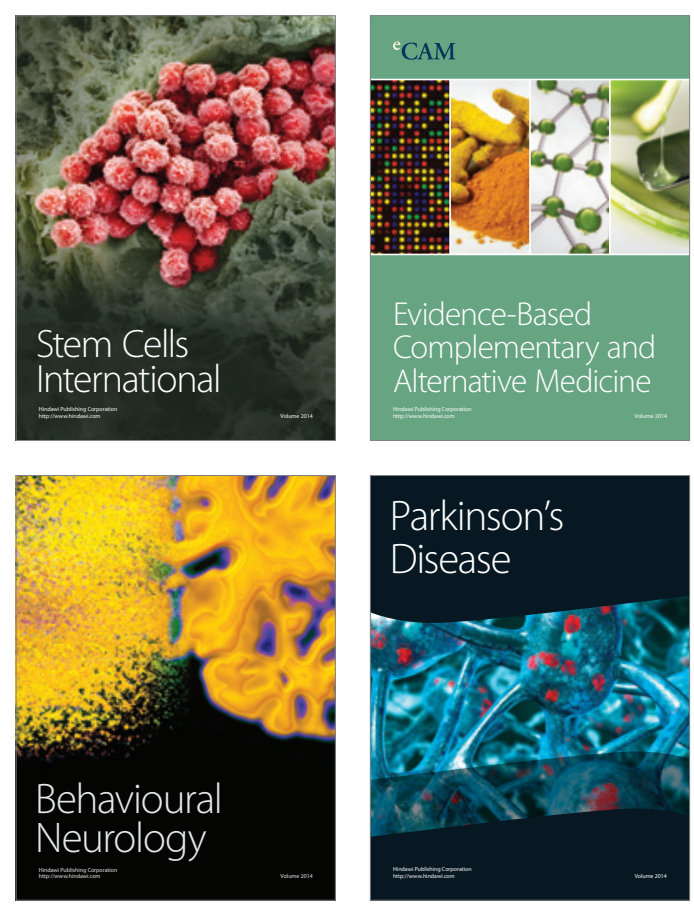

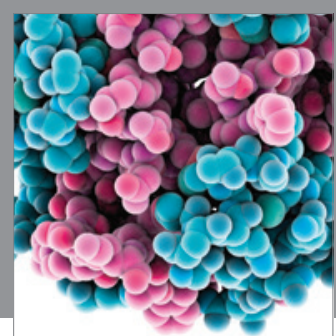

Journal of
Diabetes Research

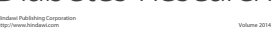

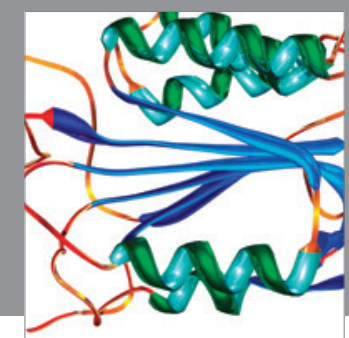

Disease Markers
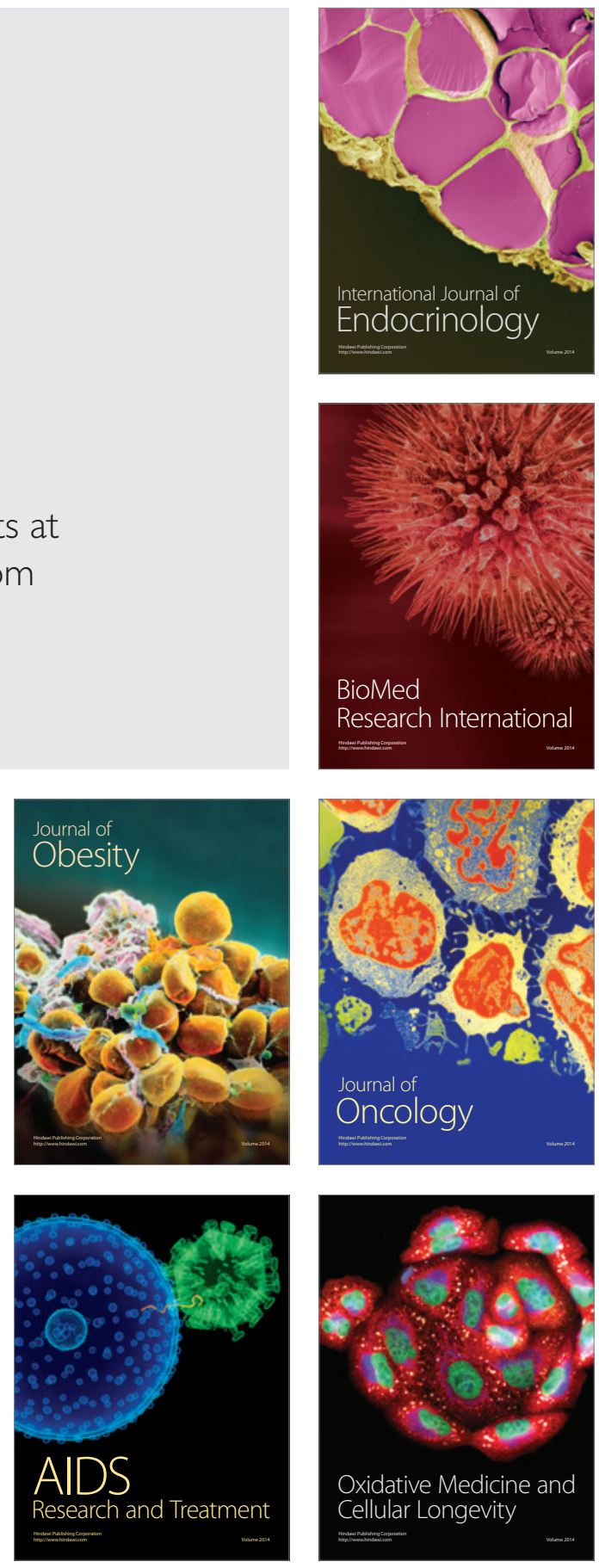